\title{
Tweeting for peace? Twitter and the Ardoyne parade dispute in Belfast, July 2014 by Paul Reilly
}

\begin{abstract}
This paper explores how social media can facilitate peace building by focusing on how citizens used Twitter during a contentious march in the Ardoyne district of North Belfast in July 2014. Fears of a repeat of sectarian clashes seen a year earlier were not realized, and the study was designed to empirically investigate whether critics and supporters of the Orange Order used the microblogging site to help reduce the sectarian tensions that surrounded the contentious parade. In particular, it focused on how users responded to rumors and disinformation spread on the micro-blogging site, which had the potential to incite violence in the contested interface area. The nature of the debate amongst those 'tweeters' who commented on the contentious Ardoyne parade was also investigated, with a focus on how they framed the attitudes and behavior of the 'other' community during these events. Results indicate that the majority of tweeters praised both sides for keeping the parade and related protests peaceful. However, Twitter did not appear to be a shared space capable of fostering cross-community consensus on how to resolve the parade dispute. The study suggests that Twitter's most significant contribution to peace building in Northern Ireland might lie in its empowerment of citizens to correct rumors and disinformation, which have the potential to exacerbate sectarian tensions and generate intercommunal violence.
\end{abstract}

\section{Contents}

Introduction

Peace building and reconciliation in Northern Ireland

New media and intergroup contact within divided societies

Twitter and affective publics

Social media, community relations and the 2013 union flaq protests

The Ardoyne parade dispute

Research questions

Sample

Critical thematic analysis

Results and discussion

Conclusion

\section{Introduction}

Peace building is a somewhat elastic concept that can be defined as "any activity that fosters or supports sustainable structures and processes that strengthen the prospects for peaceful coexistence and decrease the likelihood of the outbreak, reoccurrence or continuation of violent conflict" [1]. As far back as the late sixties, Galtung (1967) predicted that the rapid growth of media technologies would favor associative rather than dissociative approaches towards peace building. A prerequisite for this 'positive' peace was the creation of shared spaces in which antagonistic groups would be able to reconcile their differences and agree to work together for mutual benefit (Lederach, 1997).

Much of the early literature on cyberspatial technologies suggested that the Internet had the potential to facilitate this intergroup contact within highly segregated societies, where neutral space might be difficult to access (Dahlgren, 2005). Cyberoptimists frequently invoked the Habermasian public sphere in their characterizations of online spaces as electronic agoras in which people would listen respectfully to each other and reflect upon their own views on a range of issues (Froomkin, 2003). However, a more pessimistic interpretation of these online spaces has since emerged, which suggests that they promote homophily and exacerbate divisions between different social groups (Ellison, et al., 2007; Sunstein, 2007). Similar trends have been observed on the social media sites that are synonymous with Web 2.0, the term used by O'Reilly (2005) and others to describe the section of the World Wide Web that revolves around user-generated content. While sites such as Facebook have been said to provide unprecedented 
opportunities for citizens to participate in a 'networked public sphere' (Benkler, 2006), many of these new voices are still unlikely to be heard beyond like-minded individuals (Hindman, 2009).

This paper will explore how social media might facilitate peace building by focusing on how citizens used Twitter during a contentious Orange Order march in the Ardoyne district of North Belfast in July 2014. A year earlier there had been four days of mainly loyalist rioting in Ardoyne and several locations across Northern Ireland, after the Northern Ireland Parades Commission rerouted the return leg of the annual 12 July ('The Twelfth') parade away from the Ardoyne shops, situated near a sectarian interface dividing predominantly Catholic and Protestant neighborhoods in North Belfast. Contrary to expectations, in July 2014, most Orange Order parades across Northern Ireland passed off without incident. Northern Ireland Secretary of State Teresa Villiers praised the Orange Order, as well as nationalist and unionist political representatives, for helping deliver the most peaceful Twelfth in recent years [2] ]. While it is beyond the scope of this paper to fully explore these events, the ways in which critics and supporters of the Orange Order used social media to express their views about the contentious parade merit analysis.

This study was designed to empirically investigate how tweeters used the microblogging site in July 2014. In particular, it focused on how users responded to rumors and disinformation spread on Twitter, with potential to inflame sectarian tensions and incite rioting. As Young (2014) noted, such disinformation may contribute to communal violence in contested urban interface areas, as well as having a negative impact upon cross-community relations in areas such as North Belfast. The nature of the debate amongst those 'tweeters' who commented on the contentious parade was also investigated, with a specific focus on how they framed the attitudes and behavior of the 'other' community during these events. The paper begins by reviewing the relevant literature on new media and conflict transformation in Northern Ireland, and presents the key findings from a critical thematic analysis of the themes that emerged from comments posted on Twitter in relation to events between 11 and 14 July 2014.

\section{Peace building and reconciliation in Northern Ireland}

After 30 years of violence, what has been achieved in Northern Ireland since the late nineties might best be described as 'negative' peace, defined here as the "absence of organized collective violence" [ $\underline{3}$ ]. There has been an overall reduction in sectarian violence despite intermittent campaigns of 'spoiler' groups, in particular violent dissident Republicans such as the Real IRA (Edwards and McGrattan, 2010). However, the 1998 Belfast Agreement (also known as the Good Friday Agreement) has had little impact upon the ethno-national divisions within Northern Ireland, with the zero-sum perceptions of politics and territory held by Catholic Nationalists and Protestant Unionists left unchallenged (Komarova, 2011). This 'competition of victimhoods' between Unionists and Nationalists has arguably been perpetuated by a consociationalist framework, based on mandatory powersharing between political elites drawn from the two main ethnic blocs, which has appeared to prioritize group rights over those held by individuals who wish to move beyond such ethno-sectarianism (Aughey, 2005).

Many scholars have argued that a broader and more inclusive approach towards peacebuilding, involving the state, civil society and grassroots political organizations from both ethnic blocs, is needed in order to foster positive peace in Northern Ireland (Brewer, 2010; Dixon, 2012). Such an approach was said to provide opportunities for reconciling differences and building positive relationships between members of antagonistic groups (Hamber and Kelly, 2004). The primary objective of this reconciliation framework was not to minimize the importance of group affiliations; rather it was to ensure that these individuals treated each other as humans rather than anonymous members of outgroups (Lederach, 1997). This conceptualization of reconciliation is congruent with the contact hypothesis first put forward by Allport (1954) and elaborated more recently by scholars such as Hewstone, et al. (2005), which suggested that increased levels of intergroup contact can help reduce the negative stereotyping of outgroups in multi-ethnic societies. Some evidence suggests that children educated in integrated schools are more likely to reject traditional Unionist and Nationalist identities, holding out the possibility that this form of contact with the 'other' community could help reduce prejudice against outgroups in Northern Ireland (Paolini, et al., 2004). However, only around seven percent of children are currently educated in integrated schools (Hansson, et al., 2013) and research conducted over the past decade has shown that young people, particularly those who live in the vicinity of interface areas, believe that there are no safe places in which they can interact with members of the other community (Lewis, et al., 2008). This lack of shared space was recognized in the Good Relations Strategy launched in May 2013, which aimed to provide more spaces and opportunities for intergroup contact through measures such as increased provision of shared educational facilities (OFMDFM, 2013).

\section{New media and intergroup contact within divided societies}

There has been much debate about whether online spaces could facilitate intergroup contact and reconciliation within divided societies. The early cyber enthusiast literature suggested that the lack of interpersonal cues present in computer-mediated communication would reduce the anxiety associated with intergroup contact (Wang, et al., 2009). Mamadouh (2003) reported that Web sites could function as a platform for cross-cultural exchange between Muslims and non-Muslims in the Netherlands, challenging negative stereotypes of the former in the wake of the September 11 attacks. However, the social identity model of deindividuation effect (SIDE) suggests that people may be more sensitive to the social cues expressed during such online interactions than previously thought (Postmes and Baym, 2005). For example, research conducted in Singapore and the United States found a high degree of homophily in the online social networks used by students for information sources (Cho and Lee, 2008). This study also 
provided further support for the 'law of group polarization' (Sunstein, 2007), which suggested that individuals almost invariably choose to participate in online communities that share their values.

Peace on Facebook is a project created by Facebook in partnership with Stanford University, which has suggested that social media might provide the space for dialogue between social groups that are divided along ethnic or sectarian lines [4]. The social media site claims to have facilitated 'friendships' between individuals drawn from a range of antagonistic groups, including Russians and Ukrainians during the recent armed conflict. However, little information is available on the nature of these interactions and it is also difficult to verify the representativeness of participants. This 'self-selection' problem has also been identified as a potential obstacle to using virtual spaces to host deliberative consultations in divided societies. While acknowledging that 'participatory distortion' exists in both online and off-line contexts, Fishkin (2009) argued that the absence of interpersonal cues in online spaces would make it harder to foster the mutual understanding that is required in deliberative polls. It might be more appropriate to consider online contact as the first stage in a process that leads to the richer intergroup contact discussed earlier. The gradual model proposed by Amichai-Hamburger (2006) suggests that text-only interactions in shared online spaces can help build the trust and reciprocity needed for face-to-face interactions between members of different social groups.

\section{Twitter and affective publics}

This paper adds to this debate by exploring whether Twitter can be conceptualized as a shared space in which antagonistic groups can work together to prevent the reoccurrence of conflict.

Twitter can be differentiated from other social media sites due to the short length of each post (each tweet is limited to just 140 characters) and the relative ease with which they can be redistributed beyond each user's direct social network (Murthy, 2013). There has already been some evidence to suggest that Twitter can contribute to peacebuilding, most notably through the crowdsourcing of crisis information and the correction of rumors and disinformation (Procter, et al., 2013). Hashtags and news streams mobilize 'affective publics', those users who are "connected or disconnected through expressions of sentiment" [ㄷ]. Although these tweeters may be exposed to a broader range of viewpoints, the networked public formations on Twitter still largely conform to the pattern of homophily observed on other social media sites (Murthy, 2013). Nevertheless, this study explored whether 'conflictual consensus' was evident between Loyalist and Republican tweeters who presumably held widely divergent view on the Ardoyne parade. Mouffe (2013) coined this term to describe the process whereby the domestication of conflict would lead to respectful disagreement about contentious issues between former enemies (recast as adversaries).

\section{Social media, community relations and the 2013 union flag protests}

Previous research indicates that Loyalist and Republican community workers have tended to favor faceto-face contact as a means to encourage contact between communities separated by 'peace walls', primarily because the content and tone of online communication might be misinterpreted (Reilly, 2012). They are also wary of the potential for social media to be used to exacerbate sectarian tensions, given that sites such as Facebook have been used to organize anti-social behavior within interface areas (Reilly, 2011).

Social media had appeared to reinforce sectarian divisions during the 2013 union flag protests about the decision of Belfast City Council to fly the union flag above Belfast City Hall on a number of designated days each year, rather than all year round. Subsequent Loyalist protests disrupted rush hour traffic across Northern Ireland for two months from December 2012. Most of these protests passed off without incident, but in early 2013 police came under sustained nightly attack from rioters in the Short Strand/Lower Newtownards Road area of East Belfast. Loyalist paramilitaries were said to be using sites such as Facebook and Twitter to orchestrate this violence, with young people reporting a concurrent increase in online sectarian abuse and threats (Young, 2014). Statistics showed that 2,111 social media related incidents had been reported to the police between January and May 2013, compared to 2,887 during the entire calendar year of 2012 (Spencer, 2013), and two loyalist Facebook pages were shutdown via a court injunction after threats were posted [ $[\underline{6}]$.

Hashtags such as \#takebackthecity and \#Operationstin were used to mobilize affective publics in support of businesses in Belfast that suffered a massive downturn in trade due to the disruption [7]]. The self-styled 'parody group' Loyalists Against Democracy (LAD) was heralded by commentator Newton Emerson as the 'online sensation of the year' for their use of Facebook to share sectarian and offensive comments posted by Loyalists online [8]. They also shared memes mocking Loyalists using the hashtag \#flegs, a colloquial pronunciation of the word 'flags' [9]. This was said to have generated much hurt and anger amongst Loyalists. LAD were accused of reinforcing middle class stereotypes of working class Loyalists by mocking the poor spelling and grammar of those who left comments on the flag protest pages (Mulvenna, 2013). In this way, social media have previously appeared to exacerbate sectarian divisions rather than building conflictual consensus in Northern Ireland. 
After the July 2013 ruling by the Parades Commission that prevented the return leg of an Orange Order parade from going past the Ardoyne shops, 70 PSNI officers were injured during four consecutive nights of what was characterized as "animalistic" violence, which spread to other areas including East Belfast and Portadown [10]. The subsequent failure of political representatives on both sides to broker a solution to this impasse, highlighted by the continued presence at the time of writing of a loyalist protest camp in nearby Twaddell Avenue, led many observers to fear that there would be a repeat of this violence in 2014.

Tensions in the Ardoyne area were further raised when the leaders of the main Unionist political parties, together with loyalist community representatives and the Orange Order, announced that they were planning a 'graduated response' to the Parade Commission's decision to alter the route of the return parade for the second year in a row. Further details on this were released on the eve of the controversial Ardoyne march, including plans for a six-minute pause at all Orange marches on the Twelfth to represent the time it would take for the North Belfast march to return home via its traditional route and a series of peaceful protest parades later that evening [11]. These plans were heavily criticized by the two nationalist resident groupings, the Crumlin Ardoyne Residents Association (CARA) and the Greater Ardoyne Residents' Collective (GARC). In response, a member of GARC would unsuccessfully try to obtain a high court injunction that would have prevented the outward leg of the parade from passing the Ardoyne shops on the morning of 12 July 2014 [12].

There was already some evidence to suggest that social media was being used to both escalate and deescalate tensions between nationalist residents and the Orange Order in the run up to the Twelfth. Loyalists reacted angrily to the rumors suggesting that an image of Oscar Knox, a five-year old who died from a rare form of childhood cancer, had been burnt on an 'Eleventh night' bonfire in Randalstown, County Antrim [13]. A picture supposedly showing the bonfire began to circulate on Twitter late on 11 July, prompting many angry responses. These rumors were quickly refuted and condemned by Loyalists, who used Twitter to 'name and shame' two accounts that they believed to be responsible for starting them. Many shared visual evidence showing that the image had been photoshopped (Reilly, 2015). Further evidence that the image of Oscar Knox had been digitally inserted into the picture emerged later that evening. One tweet provided a link to the original image of the bonfire that had been taken by photographer Stephen Barnes in July 2013 [14]. The image of Knox that had caused so much anger amongst Twitter users a few hours earlier was noticeably absent from this picture. It was noticeable that the number of tweets about the Knox incident sharply declined after visual counter-evidence began to circulate online.

Despite the seeming inevitability of further violence, both the Orangemen and the Ardoyne residents were widely praised for the parade passing off without incident in July 2014. This study investigated what role, if any, tweeters played in preventing a repeat of the violence seen in 2013. Previous research has suggested that the sharing of disinformation on social media sites had contributed to intercommunal violence in contested urban interface areas (Young, 2014). Therefore, this paper will focus specifically on how users responded to rumors and disinformation that were circulated on Twitter, presumably with the intention of inflaming sectarian tensions in the area.

\section{Research questions}

Specifically, there were two research questions that emerged from the preceding literature review:

1. To what extent did supporters and opponents of the Orange Order appear to be using Twitter to reduce the sectarian tensions surrounding the contentious Ardoyne parade?

2. How did these tweeters respond to rumors and disinformation relating to the Ardoyne parade?

\section{Sample}

These questions were explored through a critical thematic analysis of tweets posted on Twitter between 11-14 July. This period included a number of key events relating to the 2014 marching season, ranging from the 'Eleventh night' bonfires to the outward and return legs of Orange Order parades across Northern Ireland. It was anticipated that those eyewitnesses who wished to share their perspectives on these events would have done so within this 72-hour period. It was also expected that these tweeters would refer to any rumors and disinformation that had been circulating online. Tweets were archived for analysis using the text-mining software tool DiscoverText (discovertext.com).

\section{Ardoyne}

A keyword search, 'Ardoyne' was used to identify tweets that referred specifically to the decision to reroute the parade of the Ligoniel Orange lodges, and related flute bands such as the Pride of Ardoyne $(P O A)$, in North Belfast. A total of 1,842 tweets were identified that mentioned the name of the North Belfast district. The 'Ardoyne' tweets peaked at 7pm on 12 July (see Fiqure 1). One interpretation of this finding might be that that viewers of 'flagship' teatime news programmes such as BBC Newsline and UTV Live, which had provided coverage of the day's events, had turned to social media to seek out information about the 'homeward' leg of the parade. 


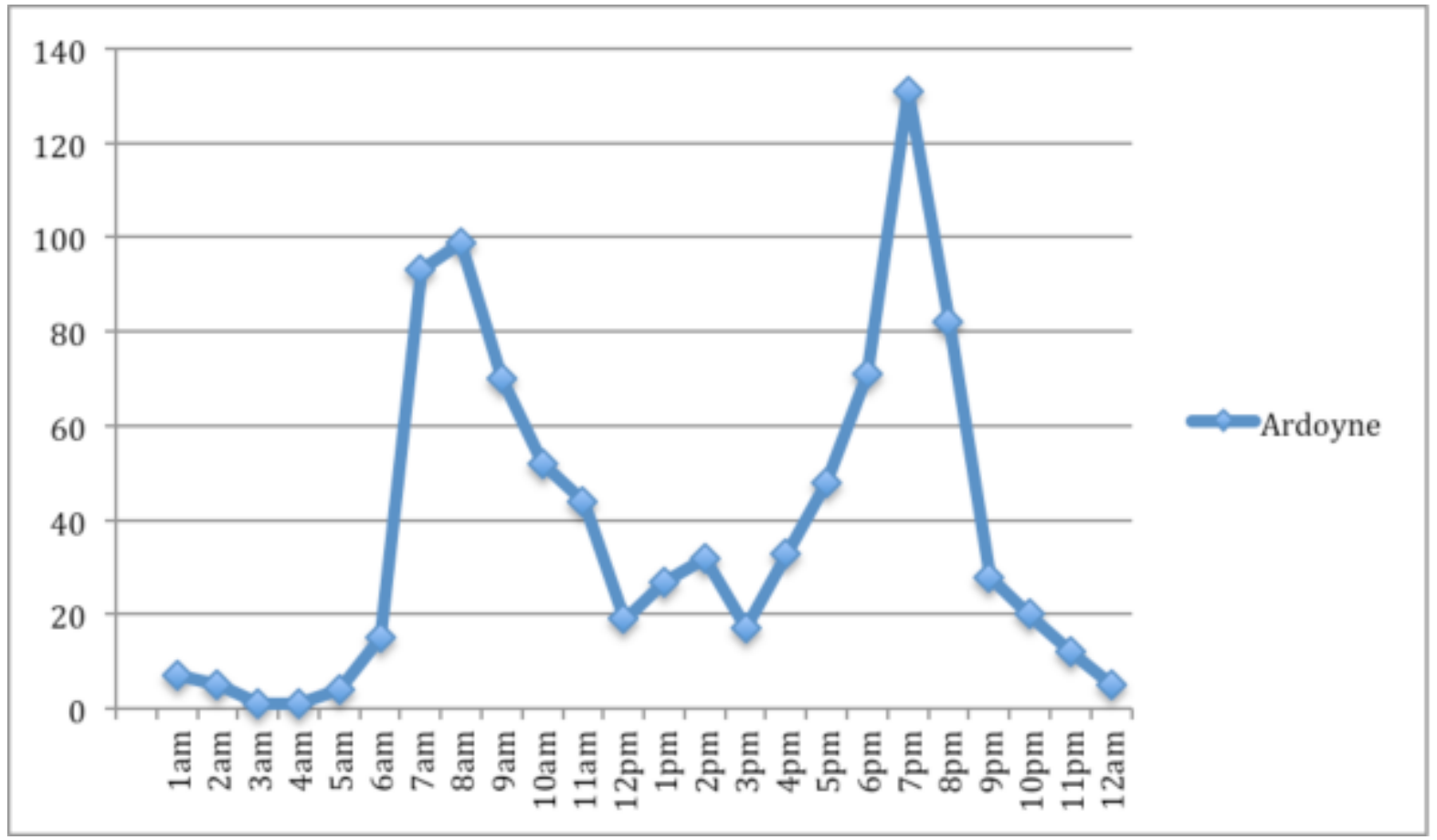

Figure 1: Tweets mentioning Ardoyne, 12 July 2014.

The corpus consisted primarily of retweeted content ( 64 percent), followed by original tweets (25 percent) and @replies to other users (11 percent) (see Fiqure 2). This would appear to suggest that there was very little direct interaction between these tweeters. However, tweeted responses that did not explicitly mention 'Ardoyne' might not have been collected due to the aforementioned keyword search used to create the corpus.

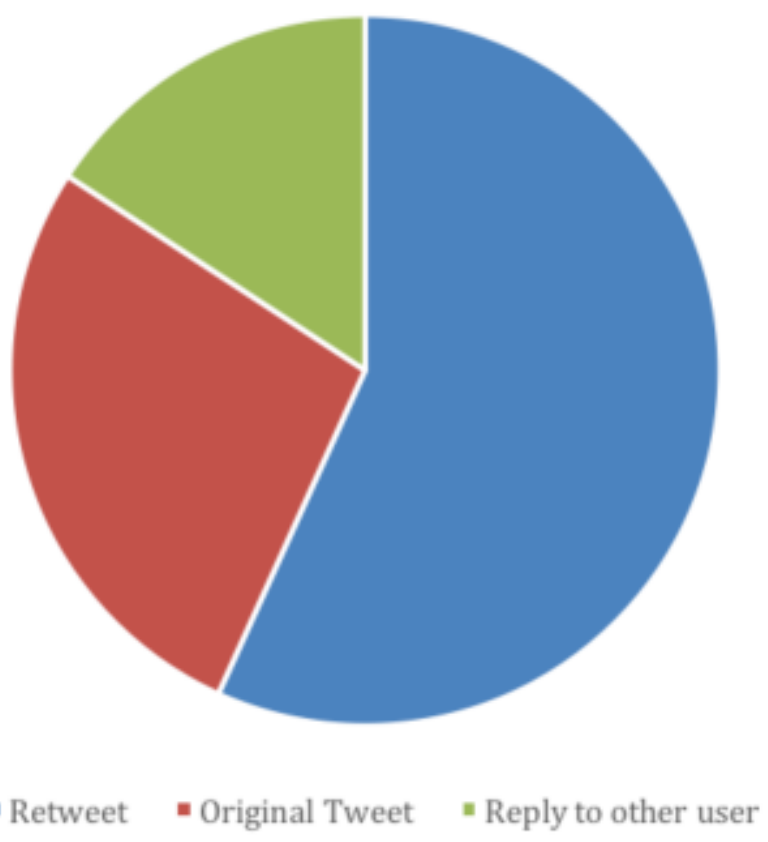

Figure 2: Classification of 'Ardoyne' tweets.

\section{Geotagged locations}

Only 21 of these tweets had been geotagged by their respective authors, with the majority (14) based within Northern Ireland. Closer inspection of these data revealed that six of these had been geotagged within 6.5 miles of the Ardoyne district of North Belfast. There were also geotagged tweets in cities and towns situated in Italy, Portugal, the Republic of Ireland, Scotland and Saudi Arabia. Although few of 
these tweets contained geotagged locations, it would be reasonable to presume that most tweeters were not physically present in North Belfast. Hence, there was a tendency for these users to retweet the content produced by eyewitnesses and professional journalists rather than share their own first-hand perspectives on events as they unfolded.

Profile of 'Ardoyne' tweeters

The study found a long-tail distribution of user activity within 'Ardoyne'. A total of 1,025 tweeters were identified in the corpus, the majority of whom (717) posted only one tweet during this period. This was congruent with previous research into political debates on Twitter, which observed a "lopsided distribution among commenters" [15]. Indeed, the 50 most prolific contributors to 'Ardoyne' accounted for 438 tweets (or 23.78 percent of the corpus). They consisted mainly of citizens (54 percent) whose bios contained no information pertaining to their socio-political identity (see Fiqure 3 ). There were noticeably fewer of these accounts that were linked to traditional news media organizations (10 percent), such as UTV, and mainstream new media organizations, such as Nuzhound. While local blogger Ardoyne Republican (@RepublicanUnity) was the most frequent contributor to this Twitter stream (27 tweets, or 1.47 percent), both loyalist (UPRG) and republican (Sinn Fein) Twitter accounts were equally represented in the list of the top 50 contributors (four percent respectively).

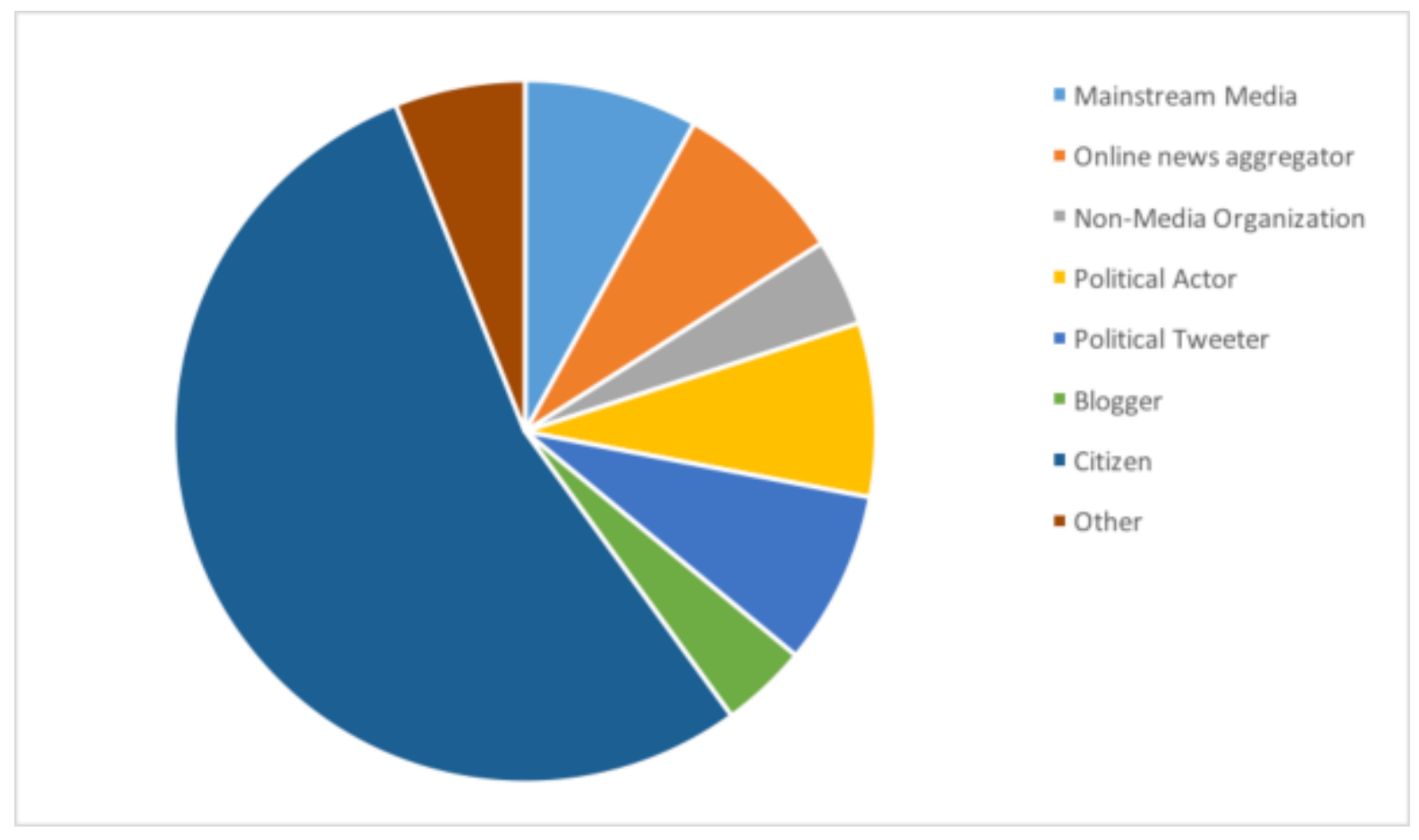

Figure 3: Top 50 'Ardoyne' tweeters by actor type.

A similar trend was observed across the entire dataset. A clear majority of the 'Ardoyne' tweeters (64.5 percent) were citizens who did not, at least openly, express support for any of the main political parties on their Twitter profiles. Fewer of these accounts belonged to political tweeters (11.71 percent), professional journalists and news media organizations (7.22 percent), bloggers (2.73 percent), mainstream new media organizations, such as Nuzhound ( 2.73 percent), and non-media organizations such as the Northern Ireland Community Relations Council (2.34 percent) combined. Members of several political parties including the Democratic Unionist Party (DUP), Progressive Unionist Party (PUP), Social Democratic and Labour Party (SDLP) and Sinn Fein were also present in the corpus (4.78 percent), with representatives of the latter the most visible (21 users or 2.04 percent). It should also be noted that those Twitter users categorized as 'Other' (3.99 percent) included a number of parody accounts, bots and academic researchers.

\section{Retweeted content}

The study identified 206 tweets that had been retweeted 1,312 times during the period of data collection. Citizens were responsible for the largest proportion of these tweets ( 31.7 percent), closely followed by professional journalists and traditional news media organizations (29.61 percent). Five political parties (Alliance, DUP, Northern Ireland Conservatives, PUP, SDLP and Sinn Fein) were retweeted under 'Ardoyne', either via tweets from their official Twitter accounts or those of their representatives. Although some of these will be explored in more detail below, it is worth noting that the PUP (41.67 percent) and Sinn Fein (25 percent) accounted for the majority of the party tweets relating to Ardoyne that were retweeted. Political tweeters were responsible for nearly three times as many of these tweets as the representatives of the main political parties in the region (see Figure 4). They were most likely to identify themselves as Loyalists (44.4 percent) or Republicans ( 30.55 percent) on their Twitter profiles. Elsewhere, there was very little to differentiate between the proportion of retweeted content that had 
originally been authored by bloggers, mainstream news media organizations and non-media organizations.

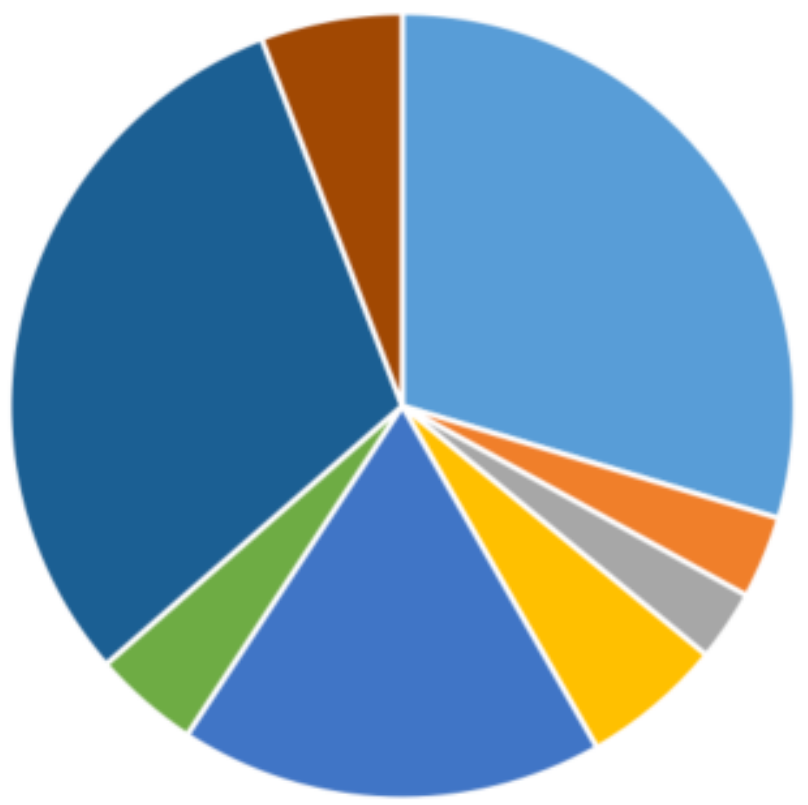

- Mainstream Media

- Online News Aggregator

- Non-Media Organization

" Political Actor

- Political Tweeter

- Blogger

- Citizen

- Other

Figure 4: Authors of retweeted content in \#Ardoyne.

However, professional journalists and public figures authored the most retweeted content in 'Ardoyne'. The former provided real-time commentary on the parade's outbound and return journeys, frequently observing that there was very little to report. For example, there were 17 retweets for a post by UTV journalist Marc Mallett, which confirmed: "Orange March past Ardoyne shop fronts has passed peacefully. Roads now reopened." Many of these tweets were accompanied by images that corroborated the reports that this was one of the quietest Twelfth demonstrations in years. The latter consisted mainly of local celebrities and entertainers. For example, the most retweeted post in the corpus (145 retweets, 86 favorites) belonged to comedian and actor Tim McGarry, who jokingly made reference to the public furore over Garth Brook's cancellation of several concerts in Dublin as a solution to the Ardoyne dispute:

If Garth Brooks would agree to play the Ardoyne shops on the 12th we could solve all of Ireland's problems.

One interpretation of such content was that it was trying to offer a counterpoint to scenes of sectarian violence from Ardoyne in 2013 that were dominating media coverage of the 2014 parade. This was arguably congruent with how citizens used hashtags such as \#positiveni and \#operationsitin to share positive images of Northern Ireland at the peak of the flag protest movement in January 2013.

A small minority of the tweets in the corpus was deemed non-relevant to the study. Most notably, a picture posted by BBC Northern Ireland (BBC NI) television reporter Mark Simpson on 27 June 2014, showing a cross-community 'sleep-out' in Ardoyne, was retweeted 53 times (and 'favorited' 55 times) during the period of data collection. There were also a few tweets circulating during this period that promoted community events, such as a family fun day due to be held by the Ardoyne GAA club in July. Although professional journalists were responsible for the most frequently retweeted content in the sample, this study focuses specifically on the themes that emerged from the tweets posted by citizens.

There were three limitations that should be acknowledged. First, the dearth of geotagged tweets makes it difficult to say with certainty that many of the Northern Irish tweeters discussed above were actually in a position to influence or report on events on the ground. Therefore, this study assessed the extent to which geographically dispersed affective publics appeared to be helping reduce sectarian tensions around the contentious parade Second, despite DiscoverText allowing researchers access to the complete public data stream of Twitter (the 'firehose'), it is difficult to verify the representativeness of these tweets. It is also possible that some tweeters may have been talking about the Ardoyne parade without using some of these keywords. Third, these tweets should be viewed as the "traces of behavior" of a small but vocal minority that lack the robustness of traditional opinion polls (Mahrt and Scharkow, 2013). Although guidelines provided to journalists by organizations such as National Public Radio (NPR) indicate that retweets are de facto endorsements of the original message [16], many tweeters still provide disclaimers on their accounts such as 'retweet is not an endorsement'. Therefore, in the absence of corroborative evidence, it would be misleading to infer the attitudes of those responsible for these posts. The same might be said for those who did not express their opinion on the content of such tweets in online spaces. Previous research has indicated that the majority of individuals who access online spaces are unlikely to make public contributions (Papacharissi, 2011) and the views of these 'watchers' 
are impossible to detect using text-mining tools. Nevertheless, the purpose of this study was to analyze how (rather than why) critics and supporters of the Orange Order used Twitter to respond to contentious issues such as the rerouting of the Ardoyne parade. Therefore, it was appropriate to focus on the themes that emerged from the collected tweets despite these inherent limitations.

\section{Critical thematic analysis}

A critical thematic analysis of these tweets was conducted in August 2014. The six phases of analysis proposed by Braun and Clarke (2013), beginning with the initial reading of tweets and ending with the definition of themes that emerged from the entire corpus, were utilized in the study. Two coders read each comment initially to explore emergent themes from the data and to then decide whether this content met the requirements of the study. Field notes were used to capture relevant information, such as heavily retweeted content and angry back-and-forth exchanges between supporters and opponents of the Orange Order. The inductive construction of codes was completed through manual data analysis that focused on the words most frequently used by tweeters in their interpretation of key events. The forcefulness of these tweets, as well as the use of derogatory and sectarian language, was noted in order to assess the nature of the debate surrounding these issues, in a similar vein to previous work involving the study of YouTube comments (Reilly, 2014).

A key challenge was how to illustrate key themes that emerged from the data, and whether it would be ethical for those responsible for these tweets to be identified. Certainly, a literal interpretation of its terms of service would suggest that users should have no expectation of privacy when posting content on Twitter, thereby permitting researchers to disclose the identity of tweeters and use their words without needing to ask permission [17]. However, there is no consensus amongst social scientists about participants' perceptions of privacy, with some arguing that such studies require greater scrutiny (Zimmer, 2010). The most recent ethical guidelines for online research provided by the Association of Internet Researchers (AoIR) encouraged researchers to 'do no harm' to unaware participants, but acknowledged that 'grey areas' remain in terms of ethical decision-making (Markham, et al., 2012). These guidelines make clear that there needs to be a public benefit from exposing these participants to harm that might be caused by the use of their tweets in such studies. In this case, there did not appear to be a compelling reason for identifying those unaware participants who had unwittingly spread rumors or used intemperate language that might have been (mis)construed as inciting violence.

A 'medium-cloaked' strategy towards data anonymization was therefore adopted, primarily because it was neither feasible nor appropriate to obtain informed consent from tweeters prior to the use of their content. Direct quotes from public figures such as bloggers, politicians and professional journalists were used to illustrate key themes. However, a number of measures were taken to protect the anonymity of those unaware participants who typically lacked the resources to control information about themselves in the public domain (Kozinets, 2010). These included the removal of personally identifiable information (PII), such as user name and gender, and paraphrasing their tweets in order to avoid them being located using a search engine. This was congruent with previous research that has suggested that the granularity of using verbatim quotes from participants is not essential in order to convey the key themes that emerge from datasets (Reilly, 2014).

\section{Results and discussion}

\section{Majority of tweeters praise both sides for peaceful outcome}

The vast majority of original tweets in the sample expressed support for all those who had contributed to the morning parade passing off without incident. The few politicians who commented on Ardoyne expressed similar sentiments, albeit for different reasons. Sinn Fein MLA Gerry Kelly tweeted "hopes for calm day grows" on the morning $(9.48 \mathrm{am})$ of the Twelfth, noting that it had been the quietest 'Eleventh' night in years and that the morning parade had passed off "without trouble" [18]. With 77 retweets, this was the one of the most widely shared tweets in the corpus. Although no tweets from 'frontline' unionist politicians were found during the period of data collection, unionist political representatives such as DUP Councillor Nigel Kells used the site to express their support for the "graduated response." Such content was often tagged \#letthemhome, a direct reference to the Ligoniel Orange lodges that had yet to complete the return leg of the parade that began in July 2013. One interpretation of this finding might be that these political representatives were continuing to perpetrate zero-sum perceptions of space and politics, praising their respective constituents while criticizing the intransigence of the 'other' community. However, the same cannot be said for those members of the public who used Twitter to praise both the Nationalist residents and the Orange Order for keeping their respective protests peaceful. Many of these tweeters made no reference to the broader political context in which the parade dispute had occurred.

\section{Vocal minority of Loyalists and Republicans blame each other for dispute}

A small minority of Republicans appeared to be using Twitter to blame the Loyalists for the Ardoyne dispute, often revolving around crude stereotypes of groups and political leaders. For example, the hashtag \#reroutetheflute featured in two tweets mocking the Orange Order and its supporters for their inability to complete the return leg of the march. The 'graduated response' was also mocked in one tweeted meme which showed a picture of the Orange Order and Unionist politicians at its launch, alongside the caption "The Last Supper". Loyalists were characterized as a "sectarian hate mob," emasculated by the Parades Commission and lacking the "muscle" to force their way past the Ardoyne shops. Few of these tweeters praised the Orange Order for the role they played in ensuring the morning 
parade passed off without incident. Indeed, one predicted that it would likely "kick off" during the return parade later that evening and suggested that the morning parade should also have been rerouted away from the Ardoyne shops.

These tweeters often highlighted the sectarianism of the marchers as the reason for their continued opposition to the contentious parade. YouTube footage of the violence seen in July 2013 was held up as evidence of the "sectarian hatred" that the Nationalist residents had been subjected to as a result of this controversial parade. Pictures also circulated on showing the names of several dead Ulster Volunteer Force (UVF) members on the drum and banner of one flute band. The Orange Order was accused of "glorifying terrorism" through their decision to allow this particular band to lead the North Belfast parade. Members and supporters of the Orange Order were quick to respond to this criticism. One tweeter pointed out that this drum skin was used during a memorial parade and that it would likely be changed before the Ardoyne parade due to the Parades Commission determination. A different narrative on this issue emerged from the unverified Twitter account of a member of the band, who tweeted that the band was "proud" to display the four names on their uniform and flags.

Local blogger Ardoyne Republican (@RepublicanUnity), the most frequent contributor to this Twitter stream, identified the "militarisation" of the Greater Ardoyne community as one of the reasons why GARC opposed "unwelcome marches," such as those of the Ligoniel Orange lodges [19]. No specific examples were given of this but it is reasonable to presume that it was a reference to the heavy police presence in the area during the Twelfth each year. Contrary to the consensus view that the morning parade had passed off without incident, he also confirmed that several breaches of the Parades Commission determination would be reported to the relevant authorities [20]. The United Protestant Voice (@unitedprotestan) responded to this tweet by asking for evidence of these breaches and accusing GARC of participating in an unlawful protest against the contentious march [21]. The study also found some evidence of hostile exchanges between the Republican blogger and the West Belfast Ulster Political Research Group (UPRG). During the conversation on 7 July, the former described the latter as the "supporters of UDA fascists" in response to their claims that the Ardoyne residents were being held to ransom by "deviant Republicans" [22]. This was typical of the interactions between Loyalist and Republicans that were found in the sample. However, it should be noted that these were few in number and most tweets did not directly address other users in this way.

Like their Republican counterparts, Loyalists also used Twitter to blame other groups for the Ardoyne impasse. For instance, the Parades Commission was criticized for 'rewarding' the Republican violence in July 2012 by rerouting the return parade away from the Ardoyne shops. The police were also accused of facilitating "unlawful" GARC demonstrations against the parade on the morning of the Twelfth. However, it was the Republican movement that inevitably bore the brunt of Loyalist anger on Twitter during this period. The rerouted parade was said to be further evidence of Republican bigotry and their intolerance towards Unionist and Loyalist culture. It was therefore perhaps no surprise that there was much glee amongst these cyber Loyalists when news broke of GARC's failed bid for legal aid on 11 July. Progressive Unionist Party (PUP) representative for South Antrim Scott McDowell urged his followers to "enjoy their day" after the bid by a "very bitter GARC member" had been rejected by the high court [23] $]$.

A handful of Loyalists shared eyewitness perspectives on events as they unfolded. Much of this usergenerated content focused on the "unlawful" GARC protest at the Ardoyne shops. One seemingly sarcastic tweet, which featured an image of a large crowd gathering at the North Belfast interface, noted a large crowd of Republicans that had gathered there even though all the shops were shut. The West Belfast UPRG posted a picture of the same scene 45 minutes later, albeit from a different vantage point. This tweet described GARC as "dissident filth" engaging in an illegal protest within the "PC sterile zone" of the shop fronts, the latter presumably a reference to the Parades Commission determination [24]. Like their Nationalist and Republican counterparts, Loyalists appeared more likely to use Twitter to criticize groups, rather than individuals, who they perceived to be responsible for the Ardoyne parade dispute.

This vocal minority of tweeters called for stronger action from the Orange Order and its supporters to overturn the Parades Commission determination on the return parade. One user proposed that Loyalists should boycott businesses owned by family members of the Parades Commission. Others argued that the rerouting of the parade in the aftermath of rioting by Ardoyne residents in July 2012 showed that violence, rather than peaceful protest, was more likely to generate results. However, it should be noted that very few of these tweets used sectarian language to describe GARC and the Nationalist residents. Those that did use such language often endorsed Loyalist paramilitary groups such as the Ulster Defence Association (UDA) and were hashtagged \#nosurrender. The absence of contextual information, as well as the appropriation of Loyalist tropes by L.A.D, meant that no generalizations could be made about the attitudes of those who used such language.

\section{Twitter users move quickly to debunk rumors and disinformation}

Rumors and disinformation in the Ardoyne sample appeared to have a short life span. There was some evidence to suggest that both Loyalists and Republicans were checking the veracity of claims made by each other on the microblogging site. Loyalists were accused of digitally altering pictures in order to portray GARC and the Nationalist residents in a negative light. A picture of one of the protesters that had gathered outside the Ardoyne shops began to circulate on Twitter shortly after 7.30pm on 12 July. The placard held aloft by the protester contained a mock-up road sign indicating that the Orange Order was not welcome in the area. One tweeter suggested that this was evidence of the intolerance of Republicans and highlighted the "unlawful" nature of the GARC protests against the march. Twitter users immediately appeared skeptical of the authenticity of this image. Visual evidence suggesting that this was a photoshopped image was shared on Twitter within a few minutes. The original image showed the protester at a peaceful Christian protest at the shop fronts with his placard proclaiming "Love Thy Neighbour," rather than the anti-Orange Order slogan that had featured in the doctored image. This was corroborated by an image of the same scene, taken and shared on Twitter by BBC NI journalist Kevin 
Sharkey a few hours earlier. Many users were prompted to tweet the Twitter user responsible for sharing the photoshopped image, who was accused of spreading lies about what was happening on the ground at Ardoyne. It was perhaps no surprise that the number of retweets of the altered image declined significantly after this revelation, in much the same way as had been seen during the Oscar Knox rumor a few hours earlier.

\section{Conclusion}

The quietest Twelfth in recent years was endorsed by the majority of tweeters who contributed to the Twitter stream. The consensus amongst this affective public was that the Orange Order and the nationalist residents deserved much praise for ensuring that there was no repeat of the violence seen in the North Belfast district in 2013. That is not to say that there was much evidence of cross-community agreement on how to resolve the impasse. Rather, zero-sum perceptions of the Ardoyne parade dispute continued to be expressed by a small but vocal minority of Twitter users during this period. Republicans depicted the Orange Order as a 'sectarian hate mob' and outlined the reasons why the contentious parade was not welcome in Ardoyne. Loyalists argued that the rerouting of the return leg of the parade was further evidence of Republican bigotry towards their culture. What was perhaps surprising was that so few of these tweets used sectarian language in their attacks on members of the 'other' community. However, the limitations in the sampling strategy outlined earlier might partly explain this finding. It is also feasible that some users may have deleted or removed offensive content shortly after it had been posted, therefore making it unavailable to the researcher.

Twitter did not appear to provide the shared space that is required for the reconciling of differences between loyalists and the nationalist residents' groups in Ardoyne. There were no signs of the rational debate and deliberation that would appear to be needed in order to resolve the Ardoyne parade dispute. Much of this content was created by public figures and professional journalists, the former offering a humorous counterpoint to the negative framing of the parade dispute and the latter giving real-time updates on a contentious parade that passed off without incident. However, Twitter might not be the most appropriate platform to facilitate intergroup contact and discussions about polarizing issues such as parades and related protests. The complexities of such issues are unlikely to be explored through the exchange of messages that are restricted to just 140 characters. A related concern would be the representativeness of the Twitter users who engage in such online debates. Recent research by the Pew Internet and American Life Project has suggested that social media perpetuates the "spiral of silence," whereby people only speak in public about certain policy issues if they believe that their views are shared by others (Hampton, et al., 2014). The long-tail distribution of observable user activity showed how a few users tended to dominate this Twitter stream. However, it revealed very little about the attitudes of those users who viewed, but did not visibly engage, with this content. Therefore, generalizations about the attitudes of Loyalists and Republicans cannot be made based upon the themes that emerge from tweets that address controversial issues, such as the Parades Commission decision to ban the return leg of the Orange Order parade from passing by the Ardoyne shops. Future research should consider how such events are mediated on Facebook, identified as a key organizational platform for the union flag protests, as well as other media channels that afford users more space in which to express their opinions.

The dearth of geotagged tweets in the corpus made it difficult to assess the impact of this online activity upon the behavior of both sides of the parade dispute. Nevertheless, the study suggests that Twitter's most significant contribution to peace building in Northern Ireland might lie in its empowerment of citizens to correct rumors and disinformation. Citizens accounted for the largest proportion of both original and retweeted content. They appeared to be using the site to expose those responsible for photoshopping images, as was seen with the picture of a protester in Ardoyne. The relatively short lifespan of these rumors, not to mention the lack of mainstream media coverage they received, illustrated how effectively tweeters corrected disinformation during this period. It is reasonable to presume that this activity helped calm tensions between these antagonistic groups, particularly in light of the negative impact that rumors spread on social media had upon community relations during the 2013 union flag protests. While acknowledging its inherent limitations as a shared space for intergroup contact within Northern Ireland, this study suggests that Twitter facilitates modes of communication that have the potential to defuse sectarian tensions around contentious issues such as the Ardoyne parade dispute. No previous research has examined tweets posted during similar incidents in North Belfast where civil unrest did occur. Future research should consider whether the same pattern of countering disinformation might reduce the likelihood of violent conflict by comparing Twitter activity during situations when violence did or did not ensue.

\section{About the author}

Dr. Paul Reilly is Senior Lecturer in Social Media and Digital Society at the University of Sheffield. E-mail: $p$ [dot] j [dot] reilly [at] sheffield [dot] ac [dot] uk

\section{Acknowledgements}

This research was funded by a small grant from the Northern Ireland Community Relations Council. Many thanks to Dr. Orna Young and Sarah Reilly for their comments and feedback on earlier drafts. 


\section{Notes}

1. Bush and Duggan, 2014, p. 310 .

2. The full text can be found here: https://www.gov.uk/government/news/villiers-commends-intensivework-to-bring-about-peaceful-12th-july.

3. Galtung, 1967, p. 17.

4. For more on Peace on Facebook see here: https://www.facebook.com/peace?_rdr.

5. Papacharissi, 2011, p. 125.

6. For more, see: http://www.belfasttelegraph.co.uk/news/local-national/northern-ireland/facebookloyalist-flaq-pages-shut-down-29039564.html.

7. http://www.itv.com/news/update/2013-01-11/belfast-hits-back-with-operation-sit-in/.

8. Emerson's article can be accessed here:

http://loyalistsagainstdemocracy.blogspot.co.uk/2013/09/real-online-wonder-of-year.html, accessed on 10 August 2014.

9. Further information on \#flegs can be found here:

http://knowyourmeme.com/memes/events/northern-ireland-flaq-protests-2012-13.

10. H. McDonald, 2013. "Northern Ireland violence leaves 70 police officers injured," Guardian (16 July), at https://www.theguardian.com/uk-news/2013/jul/16/northern-ireland-violence-police-orange-order.

11. A. Rutherford, 2014. "Implement Belfast Telegraph's Ardoyne parade proposal, unionists urge," Belfast Telegraph (11 July), at http://www.belfasttelegraph.co.uk/news/northern-ireland/implementbelfast-telegraphs-ardoyne-parade-proposal-unionists-urge-30423154.html.

12. More information on these legal challenges can be found here: http://www.bbc.co.uk/news/uknorthern-ireland-28264670.

13. For an example of one of these blogs, see:

https://beingweirdlyawesome.wordpress.com/2014/07/12/horrible-people-everywhere/.

14. The original image taken by Stephen Barnes can be found here:

http://www.demotix.com/news/2246569/protestants-prepare-11th-night-bonfires-northernireland\#media-2246528, accessed 10 October 2014.

15. Anstead and O'Loughlin, 2011, p. 449.

16. For more on these guidelines see here: http://www.niemanlab.org/2014/07/at-npr-retweets-areendorsements-after-all/.

17. For more, see: https://twitter.com/tos, accessed 10 October 2014.

18. Gerry Kelly (GerryKellyMLA). "The quietest 11 th night in years and the morning parade passed Ardoyne, Mountainview and the Dales without trouble. Hope for calm day grows." 12 July 2014, 8.48 a.m. tweet.

19. Ardoyne Republican (RepublicanUnity). "Militarising the Greater Ardoyne community has and continues to be one of key reasons why GARC oppose unwelcome marches though our area!" 12 July $2014,6.14$ p.m. tweet.

20. Ardoyne Republican (RepublicanUnity). "GARC Activists, Residents and Independent Observers logged a number of breaches of determintion during this morning's march through Ardoyne." 12 July 2014, 2.42 p.m. tweet.

21. U.P.V. (Unitedprotestan). "@RepublicanUnity breaches? For instance? Did these breaches involve an unlawful protest by Garc?" 12 July 2014, 3.49 p.m. tweet.

22. Ardoyne Republican (RepublicanUnity). "@WestBelfastUPRG More bullshite from the supporter of UDA fascists!" 7 July 2014, 8.57 p.m. tweet.

23. PUP-mcdowell, scott (scottieboy32). "THE HIGH COURT BID BY A VERY BITTER GARC MEMBER TO STOP TOMORROW'S MORNING PARADE PAST ARDOYNE HAS FAILED !!!!!!!!! NOW LET'S ENJOY OUR DAY." 11 July 2014, 4.14 p.m. tweet.

24. West Belfast UPRG (WestBelfastUPRG). "GARC DISSIDENT FILTH HOLDING AN ILLEGAL PROTEST WITHIN THE PC STERILE ZONE AT ARDOYNE SHOPFRONTS \#SHAREDSPACE." 12 July 2014, 7.46 a.m. tweet.

\section{References}

Gordon Allport, 1954. The nature of prejudice. Cambridge, Mass.: Addison-Wesley.

Yair Amichai-Hamburger and Katelyn Y.A. McKenna, 2006. "The contact hypothesis reconsidered: Interacting via the Internet," Journal of Computer-Mediated Communication, volume 11, number 3, pp. 
825-843.

doi: http://dx.doi.org/10.1111/j.1083-6101.2006.00037.x, accessed 24 October 2016.

Nick Anstead and Ben O\&esquo;Loughlin, 2011. "The emerging viewertariat and BBC Question Time: Television debate and real time commenting online," International Journal of Press/Politics, volume 16, number 4, pp. 440-462.

doi: http://dx.doi.org/10.1177/1940161211415519, accessed 24 October 2016.

Arthur Aughey, 2005. The politics of Northern Ireland: Beyond the Belfast Agreement. London: Routledge.

Yochai Benkler, 2006. The wealth of networks: How social production transforms market production. New Haven, Conn.: Yale University Press.

Virginia Braun and Victoria Clarke, 2013. Successful qualitative research: A practical guide for beginners. London: Sage.

John Brewer, 2010. Peace processes: A sociological approach. Cambridge: Polity.

Kenneth Bush and Colleen Duggan, 2014. "How can research contribute to peacebuilding?" Peacebuilding, volume 2, number 3, pp. 303-321. doi: http://dx.doi.org/10.1080/21647259.2014.887617, accessed 24 October 2016.

Hichang Cho and Jae-Shin Lee, 2008. "Collaborative information seeking in intercultural computermediated communication groups: Testing the influence of social context using social network analysis," Communication Research, volume 35, number 4, pp. 548-573. doi: http://dx.doi.org/10.1177/0093650208315982, accessed 24 October 2016.

Peter Dahlgren, 2005. "The Internet, public spheres and political communication," Political Communication, volume 22, number 2, pp. 147-162. doi: http://dx.doi.org/10.1080/10584600590933160, accessed 24 October 2016.

Paul Dixon, 2012. "The politics of conflict: A constructivist critique of consociational and civil society theories," Nations And Nationalism, volume 18, number 1, pp. 98-121. doi: http://dx.doi.org/10.1111/j.1469-8129.2011.00503.x, accessed 24 October 2016.

Aaron Edwards and Cillian McGrattan, 2010. Northern Ireland conflict: A beginner's guide. Oxford: Oneworld.

Nicole B. Ellison, Charles Steinfield and Cliff Lampe, 2007. "The benefits of Facebook 'friends:' Social capital and college students' use of online social network sites," Journal of Computer-Mediated Communication, volume 12 , number 4 , pp. 1,143-1.168. doi: http://dx.doi.org/10.1111/j.1083-6101.2007.00367.x, accessed 24 October 2016.

James Fishkin, 2009. When the people speak: Deliberative democracy and public consultation. Oxford: Oxford University Press.

A. Michael Froomkin, 2003. "Habermas@Discourse.net: Toward a critical theory of cyberspace," Harvard Law Review, volume 116, number 3, pp. 749-872.

Johan Galtung, 1967. "Theories of peace: A synthetic approach to peacebuilding," at https://www.transcend.org/files/Galtung Book unpub Theories of Peace A Synthetic Approach to Peace Thinking 1967.pdf, accessed 24 October 2016.

Brandon Hamber and Gráinne Kelly, 2004. "A working definition of reconciliation," Democratic Dialogue, at http://cain.ulst.ac.uk/dd/papers/dd04recondef.pdf, accessed 24 October 2016.

Ulf Hansson, Una O'Connor-Bones and John McCord, 2013. "Whatever happened to integrated education?" at http://uir.ulster.ac.uk/27971/1/Whatever\%20happened\%20to\%20Integrated\%20Education.pdf, accessed 24 October 2016.

Keith Hampton, Lee Rainie, Weixu Lu, Maria Dwyer, Inyoung Shin AND Kristen Purcell, 2014. "Social media and the 'spiral of silence'," Pew Research Center (26 August), at http://www.pewinternet.org/2014/08/26/social-media-and-the-spiral-of-silence/, accessed 24 October 2016.

Miles Hewstone, Ed Cairns, Alberto Voci, Stefania Paolini, Frances McLernon, Richard J. Crisp, Ulrike Niens and Jean Craig, 2005. "Intergroup contact in a divided society: challenging segregation in Northern Ireland," In: Dominic Abrams, Michael A. Hogg and José M. Marques (editors). The social psychology of inclusion and exclusion. New York: Psychology Press, pp. 265-292.

Milena Komarova, 2010. "Imagining a 'shared future': Post-conflict discourses on peace-building," In Katy Hayward and Catherine O'Donnell (editors). Political discourse and conflict resolution. Debating peace in Northern Ireland. London: Taylor and Francis, pp. 143-159.

Robert V. Kozinets, 2010. Netnography: Doing ethnographic research online. London: Sage.

John Paul Lederach, 1997. Building peace: Sustainable reconciliation in divided societies. Washington D.C: United States Institute for Peace Press.

Helen Lewis, Lizanne Dowds, Yvonne McGivern and Brandon Hamber and Gillian Robinson, 2008.

"Communities in transition: An exploration of attitudinal barriers to the development of intercommunity 
relationships in a post-conflict society," report commissioned by Belfast Conflict Resolution Consortium, INCORE (International Conflict Research Institute), Belfast, at http://uir.ulster.ac.uk/9857/, accessed 24 October 2016.

Virginie Mamadouh, 2003. "11 September and popular geopolitics: A study of websites run for and by Dutch Moroccans," Geopolitics, volume 8, number 3, pp. 191-216. doi: http://dx.doi.org/10.1080/14650040412331307762, accessed 24 October 2016.

Merja Mahrt and Michael Scharkow, 2013. "The value of big data in digital media research," Journal of Broadcasting \& Electronic Media, volume 57, number 1, pp. 20-33.

doi: http://dx.doi.org/10.1080/08838151.2012.761700, accessed 24 October 2016.

Annette Markham, Elizabeth Buchanan and AoIR Ethics Working Committee, 2012. "Ethical decision making and Internet research," version 2.0, at http://aoir.org/reports/ethics2.pdf, accessed 11 October 2014.

Chantal Mouffe, 2013. Agonistics: Thinking the world politically. London: Verso.

Gareth Mulvenna, 2013. "'LAD won't fix anything'," "Special Feature: Loyalists against Democracy," The Gown (29 October), at http://issuu.com/thegown/docs/the gown october 2013, accessed 10 November 2014.

Dhiraj Murthy, 2012. Twitter: Social communication in the Twitter age. Cambridge: Polity.

Tim O'Reilly, 2005. "What is Web 2.0: Design patterns and business models for the next generation of software" (30 September), at http://oreilly.com/web2/archive/what-is-web-20.html, accessed 10 September 2014.

Stefania Paolini, Miles Hewstone, Ed Cairns and Alberto Voci, 2004. "Effects of direct and indirect crossgroup friendships on judgments of Catholics and Protestants in Northern Ireland: The mediating role of an anxiety-reduction mechanism," Personality and Social Psychology Bulletin, volume 30, number 6, pp. 770-786.

doi: http://dx.doi.org/10.1177/0146167203262848, accessed 24 October 2016.

Zizi Papacharissi, 2011. A networked self: Identity, community and culture on social network sites. London: Routledge.

Tom Postmes and Nancy Baym, 2005. "Intergroup dimensions of the Internet," In: Jake Harwood and Howard Giles (editors). Intergroup communication: Multiple perspectives. New York: Peter Lang, pp. 213-240.

Rob Procter, Farida Vis and Alex Voss, 2013. "Reading the riots on Twitter: Methodological innovation for the analysis of big data," International Journal of Social Research Methodology, volume 16, number 3, pp. 197-214. doi: http://dx.doi.org/10.1080/13645579.2013.774172, accessed 24 October 2016.

Paul Reilly, 2015. "Tweeting for peace? Twitter may help to defuse sectarian tensions in Northern Ireland," LSE British Politics and Policy (24 April), at http://blogs.Ise.ac.uk/politicsandpolicy/tweeting-forpeace-twitter-information-flows-and-the-ardoyne-parade-dispute-in-july-2014/, accessed 24 October 2016.

Paul Reilly, 2014. "The 'Battle of Stokes Croft' on YouTube: The development of an ethical stance for the study of online comments," Sage Research Methods Cases, part 1. doi: http://dx.doi.org/10.4135/978144627305013509209, accessed 24 October 2016.

Paul Reilly, 2012. "Community worker perspectives on the use of new media to reconfigure socio-spatial relations in Belfast," Urban Studies, volume 49, number 15, pp. 3,385-3,401. doi: http://dx.doi.org/10.1177/0042098012440464, accessed 24 October 2016.

Paul Reilly, 2011. "'Anti-social' networking in Northern Ireland: Policy responses to young people's use of social media for organizing anti-social behavior," Policy \& Internet, volume 3, number 1, pp. 1-23. doi: http://dx.doi.org/10.2202/1944-2866.1071, accessed 24 October 2016.

Brian Spencer, 2013. "2,887 social media offences reported to the police service of Northern Ireland in 2012," at http://www.brianjohnspencer.com/, accessed 10 September 2014.

Cass Sunstein, 2007. Republic.com 2.0. Princeton, N.J.: Princeton University Press.

Zuoming Wang, Joseph.B. Walther and Jeffrey T. Hancock, 2009. "Social identification and interpersonal communication in computer-mediated communication: What you do versus who you are in virtual groups," Human Communication Research, volume 35, number 1, pp. 59-85. doi: http://dx.doi.org/10.1111/j.1468-2958.2008.01338.x, accessed 24 October 2016.

Orna Young, 2014. "New media and young people in interface areas of Belfast," Shared Space, number 17, at http://www.community-relations.org.uk/wp-content/uploads/2014/03/Orna-Young.pdf, accessed 24 October 2016

Michael Zimmer, 2010. "Is it ethical to harvest public Twitter accounts without consent?" (12 February), at http://www.michaelzimmer.org/2010/02/12/is-it-ethical-to-harvest-public-twitter-accounts-withoutconsent/, accessed 10 December 2014. 
Received 9 June 2016; revised 24 September 2016; accepted 24 October 2016.

\section{cc) (1) \$}

This paper is licensed under a Creative Commons Attribution-NonCommercial 4.0 International License.

Tweeting for peace? Twitter and the Ardoyne parade dispute in Belfast, July 2014

by Paul Reilly.

First Monday, Volume 21, Number 11 - 7 November 2016

http://firstmonday.org/ojs/index.php/fm/rt/printerFriendly/6996/5649

doi: http://dx.doi.org/10.5210/fm.v21i11.6996 